\title{
Can Job Satisfaction Mediate the Relationship between Emotional Intelligence and Spiritual Intelligence on Teacher Performance?
}

\section{Efendi1 , Sri Harini2 ${ }^{2}$, Sudung Simatupang3 ${ }^{3}$, Marto Silalahi ${ }^{4}$, Acai Sudirman ${ }^{\text {* }}$}

1,3,4,5 Management Study Program, Sultan Agung College of Economics, Indonesia

${ }^{2}$ Management Study Program, Universitas Djuanda, Indonesia

A R T I C L E I N F O

Article history:

Received 13 December 2020

Received in revised

Form 06 January 2021

Accepted 21 January 2021

Available online 01

February 2021

Keywords:

Emotional Intelligence,

Spiritual Intelligence, Job

Satisfaction,

Teacher Performance

\begin{abstract}
A B S T R A C T
This study aims to analyze the role of job satisfaction in mediating the relationship between emotional intelligence and intellectual intelligence on the performance of the high school teachers. This study uses a research design with an associative quantitative approach. Data was collected through documentation and online questionnaires. This study used a sample of 39 respondents with the determination of the sample size using the saturated sample formula. Partial least square is applied to examine the relationship between teacher performance, job satisfaction, emotional intelligence and intellectual intelligence. The results of this study indicate that of the seven hypotheses developed there are two accepted hypotheses, that is, for the effect of emotional intelligence on job satisfaction, it is obtained that the results of a significant effect and the influence of spiritual intelligence on teacher performance are also obtained significant results. Meanwhile, the other 5 hypotheses developed were not significant. Through the findings of this study, it is hoped that it can provide additional information for various parties, especially the school, to pay attention to the factors that affect teacher performance and job satisfaction, so that teachers gain comfort and confidence to continue to improve their performance in implementing learning in schools.
\end{abstract}

\section{Introduction}

The context of the problems encountered by the Indonesian nation in the field of education is fundamentally due to the low quality of education. Educational resources in the current era of the industrial revolution 4.0 are an important part of improving the quality of education in the future (Narsih, 2017). Education is a conscious effort to establish the potential of human resources (HR) through teaching activities that aim to assist students to develop themselves optimally, which is the development of all their potential, skills, and personal characteristics in a positive direction (Butarbutar et al., 2020). The success of achieving educational goals is mainly determined by the learning process experienced by students. With the learning process, it is expected that there will be an improvement in aspects of student knowledge, attitudes, and skills (Lie et al., 2019). A good school can be seen from the teacher performance of the school, for that teacher performance needs to be well considered because good teacher performance will determine the success or failure of the school to achieve its goals (Budiwibowo, 2017). To generate the best human resources in the school environment, the presence of a teacher is necessary for carrying out their duties effectively (Pakpahan et al., 2020). Producing a good quality of education depends on the level of quality of a teacher which can be measured by their performance.

The realization of the work carried out by educators can be described from the performance of the teacher. The importance of paying attention to teacher performance will have an impact on effectiveness in achieving the educational goals set by the school (Ahmadiansah, 2016). In general, the representation of teacher performance can be seen from the performance done in the process of carrying out their duties as an educator. Teacher performance measures are quality-oriented which is generated in carrying out the learning process for students (Amalini et al., 2016). Teacher performance will be optimal when integrated with school components, including school principals, teachers, employees, and students. (Weliyanto, 2020). To generate good performance does not only see perfection in work abilities, but also sees the abilities possessed by each individual. This ability is in the form of intelligence, including emotional intelligence and spiritual intelligence, also the level of satisfaction (Anjarini, 2018). This 
statement was also conveyed by Sahir et al., (2020), in which an individual's response in reacting to the environment, particularly in the work environment, is holistically formed by emotional intelligence, spiritual intelligence, and job satisfaction. The presence of a teacher is one of the main factors for the emergence of a qualified future generation, not only from the intellectual side but also from the way of behaving in society.

Based on opinions of Pujianti \& Isroah (2013), they provided a definition of teacher performance as the work result that has been achieved by a teacher in carrying out their duties in accordance with the given responsibilities and tasks, including organizing learning in accordance with professional principles and achieving the goals of national education. Teachers must have a commitment to continue and never stop learning. Without it, teachers will be limited in science, even will be left behind in the increasingly uncertain acceleration of times. Teachers have the responsibility of carrying out their teaching duties in the classroom and outside the classroom (Pakpahan et al., 2019). Performance can be defined as a set of abilities that arise in a person based on knowledge, attitudes, skills, and motivation to generate something (Amalini et al., 2016). In the practice of conceptualizing the criteria for assessing teacher performance, it is necessary to consider the emphasis on performance aspects, one of which is job satisfaction. Job satisfaction simultaneously provides a stimulus for a teacher so that the results of their performance can be achieved optimally (Ahmadiansah, 2016). One of the important means of human resource management in an organization is job satisfaction. In the context of education, high job satisfaction in a teacher will help schools realize the effective implementation of education (Rahmawati \& Gunawan, 2019).

Job satisfaction is a condition where the human resources in it are satisfied with what is produced from the work they do. Conditions that explain the ability to respond to a job in general for the results of the volume of work carried out and the number of wages received is part of job satisfaction (Pamungkas \& Jabar, 2014). Job satisfaction reflects an individual's attitude towards their job. This is evident in the positive attitude of employees towards work and everything they face in their work environment (Rosita \& Yuniati, 2016). The more things in the job that suits the individual, the higher the level of satisfaction perceived and vice versa (Purwanto, 2018). Job satisfaction itself describes the attitude that an individual provides to their job to create a sense of comfort when the individual is in the organization (Auda, 2016). Findings by Alfany (2017) stated that every organization that has workers with high satisfaction tends to be more effective than organizations that have workers who are less satisfied.

Emotional intelligence is considered to improve an individual's performance and can also reduce excessive work stress. An individual who has a strong character that is called positive individual characteristics is a representation of emotional intelligence that is well managed (Daud, 2012). Psychologically, temperament is not something that comes from outside but is formed due to excessive emotional intelligence (Sahir et al., 2020). Furthermore, if individuals have negative emotional responses to work-related stress, they often manage their responses in describing a job based on their emotional point of view (Vasumathi et al., 2019). One of the differences between humans and other creatures is the emotional connection that is created because of their emotional intelligence. Self-motivation initiative and the ability to develop relationships with others are manifestations of good emotional intelligence (Rachmelya \& Suryani, 2017). Thus, in the world of education, the management of a teacher's emotional intelligence is vital in driving productivity and performance. Findings conveyed by Setyowati et al., (2019) stated that the emotional intelligence of a teacher is considered to be a vehicle in developing professionalism and better teacher performance.

In the context of education, spirituality is considered as one of the key factors for the success of educational institutions which eventually ensures the professional life of teachers (Kulshrestha \& Singhal, 2017). The ability to adjust rigid rules followed by a sensitivity to interpret life positively is part of spiritual intelligence (Mujiono \& Faruk, 2020). Every individual with high spiritual intelligence is able to interpret life with a positive meaning in every event, problem, even suffering in it (Purwanto, 2018). The level of spirituality of an individual will have an impact on broader moral reactivity and sensitivity. An individual with a high level of spirituality will be able to distinguish between self-interest and concentration on God (Khodijah, 2014). With a high level of spiritual intelligence, an individual can use their spirituality to bring common meaning, interest, and enrichment to life (Koražija et al., 2016). In the field of education, the urgency of managing a teacher's spiritual intelligence will be seen when there is a process of interaction in carrying out the learning process. Another implication can also be perceived when there is low social friction that occurs when a teacher communicates directly with students. Findings by Karimi \& Mohammadi (2020) indicated that the higher the spiritual intelligence, the less the possibility of friction of social competition in particular occupations which implies that it is expected to produce better performance.

Many studies discuss teacher performance and satisfaction by placing emotional intelligence and spiritual intelligence variables as antecedent variables. This clearly illustrates that the effectiveness of 
teacher performance and job satisfaction cannot be separated from the strong encouragement of the level of emotional intelligence and spirituality Hidayati et al., (2013), stated emotional intelligence has no effect on satisfaction. Then the research results Mulyasari (2019), stated that the increase in the performance of a teacher is not driven significantly by the level of emotional intelligence it has. Other findings that discuss the effect of spiritual intelligence on satisfaction were conveyed by Ginoga (2017), which conveys spiritual intelligence does not have a significant contribution to satisfaction. Furthermore, the research results Pande (2012), conveying that an increase in the performance of a teacher is not only influenced by spiritual intelligence. In this regard, the researcher felt the need for further research related to emotional intelligence and spiritual intelligence as predictors and job satisfaction as a mediating variable on teacher performance with the selection of research objects for private teachers who teach in Pematangsiantar City Junior High School (SMP). The main objective of this study is to determine the role of job satisfaction in mediating the relationship between emotional intelligence and spiritual intelligence in influencing teacher performance levels.

\section{Methods}

This study used a method of quantitative approach with a theoretical model assessed by PLS-SEM analysis in a two-stage process. First, the research data were analyzed for validity and reliability using Cronbach's alpha testing, composite reliability, outer loading, and average variance extracted. Then, Confirmatory Factor Analysis was carried out to check the model suitability and model reliability and discuss the hypothesis by using the variance-based Structural Equation Model (SEM) (Hair, 2014). The determination of the sample size used the saturated sampling method. The saturated sampling technique was used because the entire research population was selected as the sample as a whole. The sample used in this study were all teachers of the Sultan Agung Private Senior High School, with a total of 39 people. The measurement of the dependent and independent variables used previous references that were relevant to the research topic and research variables. The measurement of the dependent variable, which was teacher performance, was measured using the Regulation of the Minister of National Education No. 16 of 2007 which consisted of 14 items. For the mediating variable, which was job satisfaction, it was measured using a previous study by Amalini et al., (2016), which consisted of 5 items. Then for the first independent variable, which was emotional intelligence, it was measured using a previous study by Kaur et al., (2019), which consisted of 4 items. For the second independent variable, which was intellectual intelligence, it was measured using a previous study by Mantu et al., (2018), which consisted of 5 items. Therefore, the conceptual framework of this study can be explained in Figure 1.

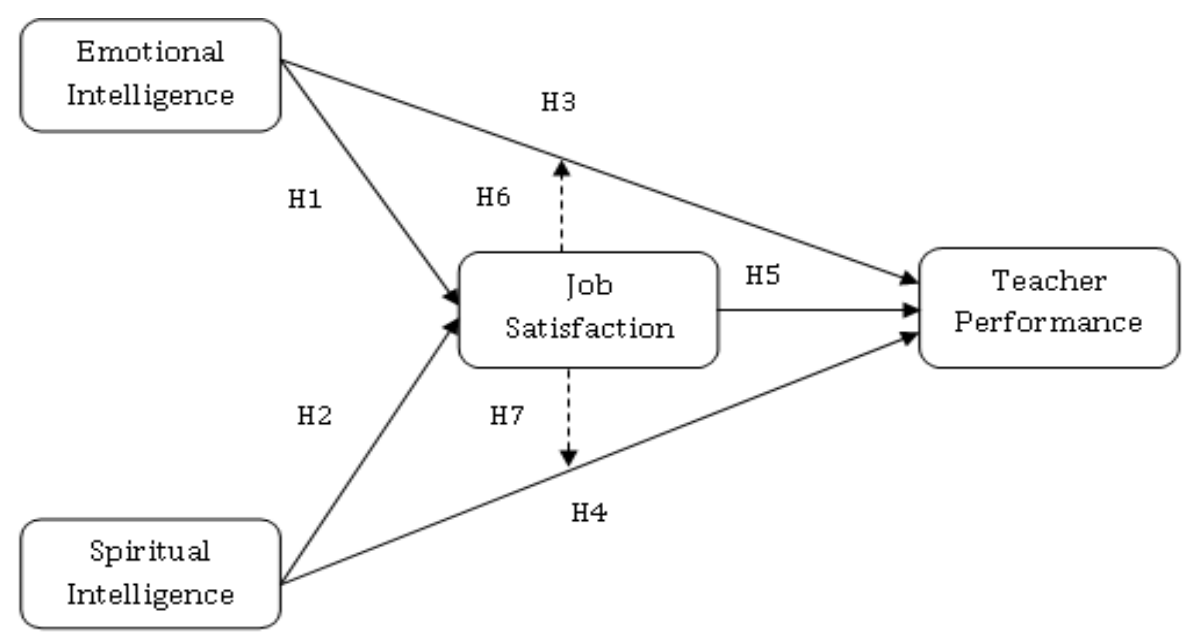

Figure 1. Theoretical Framework Model of the Study

Based on Figure 1 above which is the framework in this study, some research hypotheses can be formulated, including: emotional intelligence has an effect on job satisfaction; spiritual intelligence has an effect on job satisfaction; emotional intelligence has an effect on teacher performance; spiritual intelligence has an effect on teacher performance; job satisfaction has an effect on teacher performance; job satisfaction mediates the relationship between emotional intelligence on teacher performance; job satisfaction mediates the relationship between spiritual intelligence on teacher performance. 


\section{Result and Discussion}

The questionnaire was distributed online via WhatsApp and Telegram social media. Social media was chosen because many of the target respondents were actively using social media in their daily lives. The number of respondents who filled in the questionnaire was 39 teachers. The general characteristics of the respondents in this study will be clearly described in Table 1.

Table 1. General Profile of the Respondents

\begin{tabular}{cccc}
\hline Category & Details & Number & Percentage \\
\hline Sex & Male & 14 & $35.9 \%$ \\
& Female & 25 & $64.1 \%$ \\
& $24-28$ years & 2 & $5.128 \%$ \\
29-33 years & 4 & $10.26 \%$ \\
34-38 years & 4 & $10.26 \%$ \\
Age & $39-43$ years & 12 & $30.77 \%$ \\
& $44-48$ years & 8 & $20.51 \%$ \\
& $49-53$ years & 9 & $23.08 \%$ \\
& Associate Degree 1 to 3 & 4 & $10.26 \%$ \\
& Bachelor's Degree & 27 & $69.23 \%$ \\
Master's Degree & 8 & $20.51 \%$ \\
Length of Work as A & A year & 1 & $2.564 \%$ \\
Teacher & $1-5$ years & 2 & $5.128 \%$ \\
& 6-10 years & 4 & $10.26 \%$ \\
& $11-15$ years & 9 & $23.08 \%$ \\
& $16-20$ years & 6 & $15.38 \%$ \\
& $>20$ years & 17 & $43.59 \%$ \\
\hline
\end{tabular}

\section{Outler Model Measurement}

The results of the data obtained from the research questionnaire were processed using the SmartPLS version 3.2.9 application with processing guidelines by (Juliandi, 2018). In measuring the outer model, the tests conducted were the validity test and reliability test. A convergent validity testing is determined by the loading factor and AVE with the condition that the loading factor is above 0.7 and the AVE value is 0.5 (Hair, 2014). The model reliability test according to (Hair, 2014) is seen from the value of Cronbach's alpha and composite reliability (CR) which has a value higher than 0.7. The following will show an explanation of the measurement of the outler model, which is presented in Figure 2 and Table 2 below:

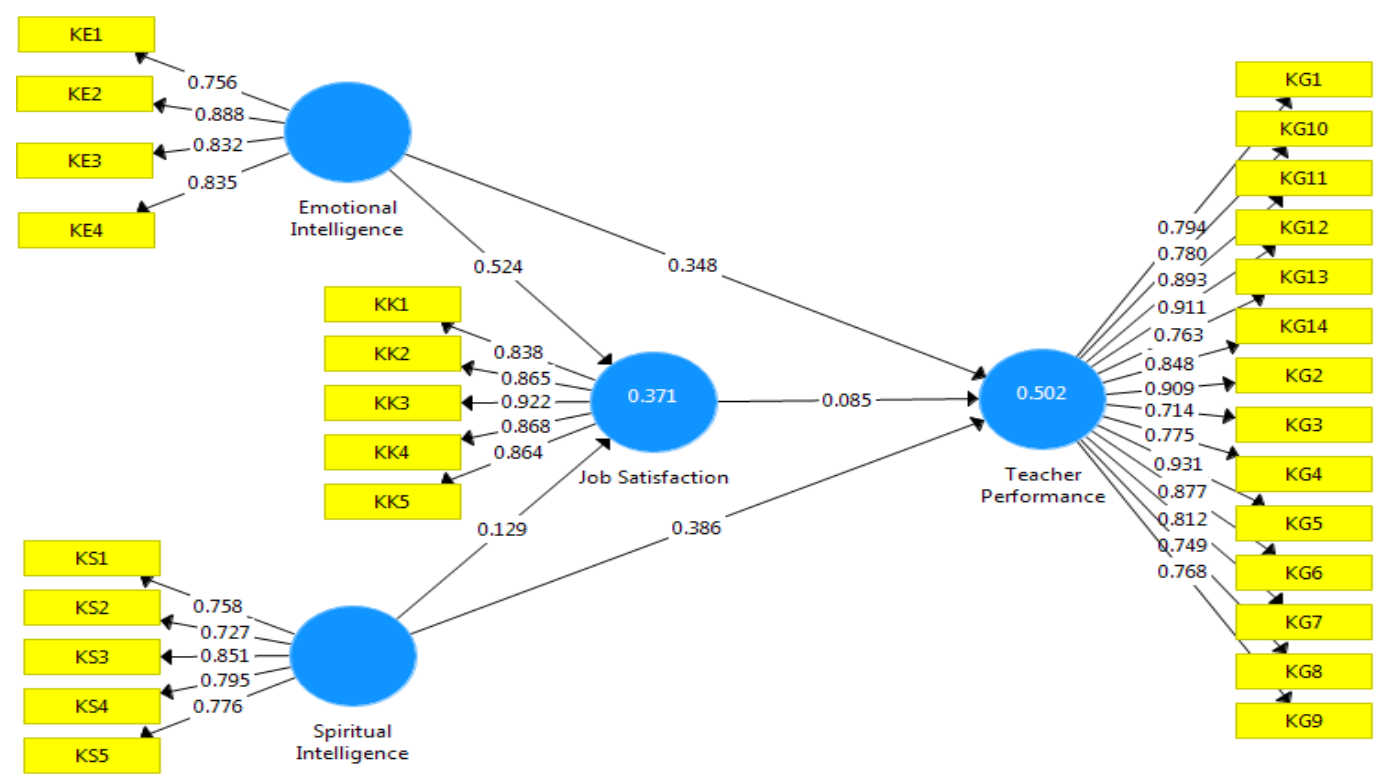

Figure 2. Outler Model Display 
Based on the data analysis, it obtained that the value of each loading factor on the indicators of the variables of emotional intelligence, spiritual intelligence, job satisfaction, and teacher performance was above 0.7 and above 0.5 for the average variance extracted (AVE) value. Moreover, the value for each reliability above obtained the composite reliability value for each research variable which was above 0.7 which can be explained as follows: emotional intelligence obtained 0.898 , spiritual intelligence obtained 0.887, job satisfaction obtained 0.941 , and teacher performance obtained 0.968 . Furthermore, for the Cronbach's alpha value, the value for each variable was above 0.7 , which showed that all research variables had good reliability values. With these good values, it can be used as an overview that the condition of the relationship between variables was also good so that further tests can be carried out.

\section{Inner Model Measurement}

Inner model measurement was carried out by bootstrapping research data using SmartPLS 3.2.9. There were two results obtained from bootstrapping, the first was the significance of the two related variables, and also the R-square of the study. The value of the R-square is the value that shows the ability of exogenous variables to build endogenous variables. According to Chin et al., (2008), there are three categories of R-square values, in which if the R-square value is 0.19 , the relationship between exogenous variables forming endogenous variables is weak, if it is 0.33 , it means that the relationship is moderate, and if the value is 0.67, it means that the relationship is strong. Meanwhile, Sarwono (2016), stated that if the R-square value is more than 0.67 , the relationship between endogenous and exogenous variables is very strong.

Table 2. Calculation results of the R-Square value

\begin{tabular}{ccc}
\hline Notes & R Square & R Square Adjusted \\
\hline Job Satisfaction & 0.371 & 0.336 \\
Teacher Performance & 0.502 & 0.459 \\
\hline
\end{tabular}

Seen from the R-square value of each endogenous variable, it obtained a value of 0.486 and for the endogenous variable of teacher performance, it obtained a value of 0.502 in which the values ranged from 0.33 to 0.67 . This showed that, overall, the ability of exogenous variables to explain endogenous variables was moderate. Furthermore, to prove the hypothesis testing, a significance test was carried out to determine the relationship between exogenous variables and endogenous variables. The criterion of significance was seen from the p-value. With a significance level of $5 \%$, if the p-value between exogenous and endogenous variables is less than 0.05 , it means that the exogenous variable has a significant effect on endogenous variables. On the contrary, if the value is higher than 0.05 , it means that the exogenous variable does not have a significant effect in formulating the endogenous variable. Then, for the mediation test between the exogenous variables and endogenous variables, the conclusion can be assessed from the p-value with a significance level of 0.05 . If the results of the mediation show a value below 0.05 , it can be concluded that the variables considered as mediation are able to mediate the relationship between the exogenous variables and endogenous variables. The results of the hypothesis testing are presented in the following Table 3 and Figure 3.

Table 3. Path Coefficients Test Results

\begin{tabular}{lcccc}
\hline \multicolumn{1}{c}{ Path Between Variables } & Coefficient & t-count & $\boldsymbol{P}$-Value & Conclusion \\
\hline Emotional Intelligence>>Job Satisfaction & 0.524 & 3.927 & $\mathbf{0 . 0 0 0}$ & Significant \\
Spiritual Intelligence>>Job Satisfaction & 0.129 & 0.722 & $\mathbf{0 . 4 7 1}$ & Not significant \\
$\begin{array}{l}\text { Emotional Intelligence>> Teacher } \\
\text { Performance }\end{array}$ & 0.348 & 1.876 & $\mathbf{0 . 0 6 1}$ & Not significant \\
$\begin{array}{l}\text { Spiritual Intelligence>>Teacher } \\
\text { Performance }\end{array}$ & 0.386 & 2.102 & $\mathbf{0 . 0 3 6}$ & Significant \\
Job Satisfaction>>Teacher Performance & 0.085 & 0.672 & $\mathbf{0 . 5 0 2}$ & Not significant \\
\hline
\end{tabular}

Based on the data presented in Table 3, it obtained that emotional intelligence had a positive and significant effect on job satisfaction as evidenced by the acquisition of a p-value of 0.000 which was below 0.05. Furthermore, spiritual intelligence had a positive but insignificant effect on job satisfaction as evidenced by the acquisition of a p-value of 0.471 which was above 0.05 . For the effect of emotional intelligence on teacher performance, it had a positive and insignificant effect as evidenced by the 
acquisition of a p-value of 0.061 , which was above 0.05 . Furthermore, spiritual intelligence had a positive and significant effect on teacher performance as evidenced by the acquisition of a p-value of 0.036 which was below 0.05 . Then, for the effect of job satisfaction on teacher performance, the results had a positive and insignificant effect as evidenced by the acquisition of a p-value of 0.502 which was above 0.05 .

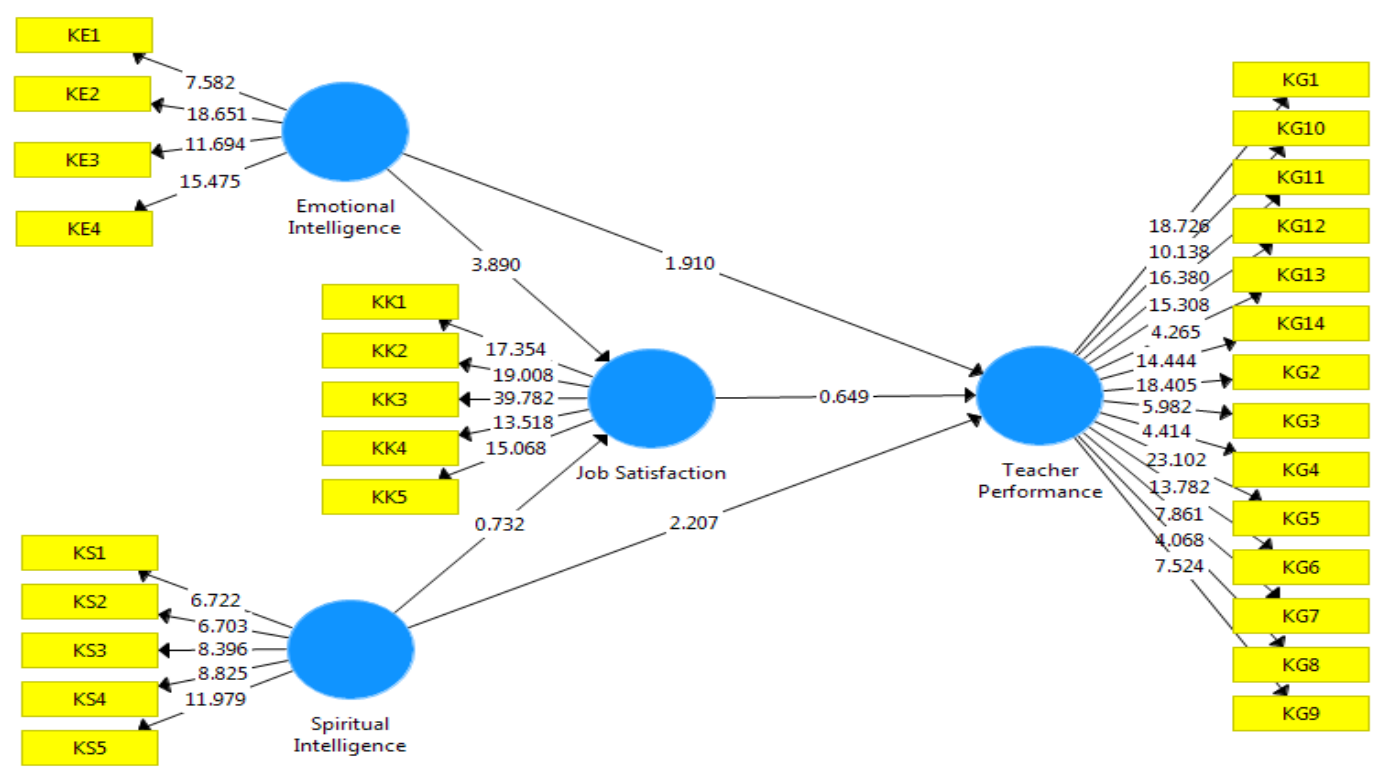

Figure 3. Inner Model Display

Table 4. Mediation Test Results Based on Indirect Effect

\begin{tabular}{ccccc}
\hline Path Between Variables & Coefficient & t-count & P-Value & Conclusion \\
\hline $\begin{array}{c}\text { Emotional Intelligence>>Job } \\
\text { Satisfaction>> Teacher Performance }\end{array}$ & 0.045 & 0.592 & $\mathbf{0 . 5 5 4}$ & Not Mediating \\
$\begin{array}{c}\text { Spiritual Intelligence }>>\text { Job } \\
\text { Satisfaction }>>\text { Teacher Performance }\end{array}$ & 0.011 & 0.031 & $\mathbf{0 . 7 2 3}$ & Not Mediating \\
\hline
\end{tabular}

Based on the results of the processed data presented in Table 4, it can be concluded that the job satisfaction variable was not able to mediate the relationship between emotional intelligence and teacher performance as evidenced by the acquisition of a p-value of 0.554 which was above 0.05 . Furthermore, the job satisfaction variable was also unable to mediate the relationship between spiritual intelligence and teacher performance as evidenced by the acquisition of a p-value of 0.723 , which was above 0.05 .

\section{Discussion}

\section{The Effect of Emotional Intelligence on Job Satisfaction}

The results of the study showed that emotional intelligence had a positive and significant effect on job satisfaction. In modern organizations, the role of emotional intelligence is immensely crucial in the development of an individual's character in carrying out their functions and responsibilities as a leader. This condition will bring an individual's character to become someone who has a high work ethic with the implication of making them have a high level of job satisfaction as well (Parawitha \& Gorda, 2017). The findings of this study are consistent with the results of studies by Slamet et al., (2020) and Argon \& Liana (2020), whose findings suggested there was a significant effect between emotional intelligence on satisfaction. On the other hand, these findings are not in line with the results of studies by Riski \& Riana (2018) and Hidayati et al., (2013), whose research findings stated there was no significant impact of emotional intelligence on satisfaction levels. This is because the placement of human resources is not right on the axis of performance development, so that the emotional intelligence of a teacher has not been able to drive the level of satisfaction in doing work. 


\section{The Effect of Spiritual Intelligence on Job Satisfaction}

The results of the study showed that spiritual intelligence had a positive but insignificant effect on job satisfaction. The results of this study are in line with Ginoga (2017) and Wahyudi (2019), whose findings stated that there was no significant effect between spiritual intelligence possessed by a teacher on job satisfaction. An individual who has good spiritual intelligence may not optimally apply it in their work-related life. The job satisfaction obtained by a teacher is basically related to what they receive from improving their performance. However, the results of this study contradict the findings presented by Mandala \& Dihan (2018); Sibasopait (2018); Robbil Alifah (2017), which stated that there was a significant effect of spiritual intelligence on the level of job satisfaction. Someone who has good spiritual intelligence will have implications for the motivation to carry out work optimally, so that the work that is considered optimal will have an impact on the level of satisfaction.

The Effect of Emotional Intelligence on Teacher Performance

The results of the study showed that emotional intelligence had a positive but insignificant effect on teacher performance. When an individual has a good mental and emotional attitude with an optimistic perspective, it is not enough to encourage them to improve their work results (Mulyasari, 2019). Limitations and inability to manage emotions result in a lack of understanding of oneself and others, so that this will have an impact on weak effectiveness at work. The research findings are in accordance with the results of a study by Yani \& Istiqomah (2016), whose findings stated that there was no significant effect of emotional intelligence on performance. The results of this study contradict the research presented by Chong et al., (2020) and Mulyasari, (2019), which stated that there was a significant effect of emotional intelligence on performance. An individual who can control their emotions wisely and well will certainly have implications for improving good performance as well (Sahir et al., 2020).

\section{The Effect of Spiritual Intelligence on Teacher Performance}

The results of the study showed that spiritual intelligence had a positive and significant effect on teacher performance. The results indicated that the higher the level of spiritual intelligence, the higher the performance. Management of the meaning of thoughts, work behavior, and giving positive energy to others are some characteristics of spiritual intelligence that aims to build good cooperation. To assess a life based on goodness and responsibility to oneself, other people, and life, spiritual intelligence is needed (Sulastyaningrum et al., 2019). The findings of this study are in line with the results of the studies by Jasour \& Maleki Avarsin (2016) and Ekowati et al., (2020), whose findings stated that there was a significant effect of spiritual intelligence on performance. However, there are several studies that conducted the same study that obtained different results from the results of this study. Studies conducted by Pande (2012), stated that spiritual intelligence had no significant effect on performance.

\section{The Effect of Job Satisfaction on Teacher Performance}

The results of the study showed that job satisfaction had a positive and insignificant effect on teacher performance. The results of this study have the same results as the findings presented by Arda (2017) and Fatati et al., (2017) which stated that the level of job satisfaction did not have a significant effect on improving performance. This is because the conditions of the non-physical work environment in schools do not support the increase in the creativity of teachers in driving learning and teaching activities. However, the results of this study are not in accordance with the study conducted by Werang (2014); Harum et al., (2015); Hidayati et al., (2013) which stated that there was a significant effect on the level of job satisfaction on performance. These findings strengthened the assumption related to the urgency of the level of satisfaction of a teacher in improving their performance. If the level of job satisfaction is good, the implication will be to improve performance in the short and long term.

\section{The Effect of Emotional Intelligence on Teacher Performance Mediated by Job Satisfaction}

The results of the study showed that job satisfaction was not able to mediate the relationship between emotional intelligence and teacher performance. If individuals have negative emotional responses to job-related satisfaction, they often adjust their own responses in describing a job based on their emotional perspectives (Vasumathi et al., 2019). These findings are strengthened by the results of the study presented by Ula (2020), whose results of the study found a situation where a teacher has skilled emotional intelligence, but if it is not supported by the level of satisfaction, the implication is that it will have an impact on decreasing performance. However, these results are not in line with the study by Usman (2019) and Auda (2016) which argued that job satisfaction was able to mediate the relationship between emotional intelligence and performance. Positive interactions make teachers comfortable at work, such as being able to solve problems related to work deadlines that should be completed by only 
one individual. But, due to high emotional intelligence, they are able to make colleagues help each other to increase job satisfaction.

\section{The Effect of Spiritual Intelligence on Teacher Performance Mediated by Job Satisfaction}

The results of the study showed that job satisfaction was not able to mediate the relationship between spiritual intelligence and teacher performance. An individual who has a high level of spirituality is often faced with the choice to perceive a different level of satisfaction. Good satisfaction in certain cases is not directly related to an individual's spiritual condition (Robbil Alifah, 2017). This is supported by a study by Pande (2012) which stated that a decline in the level of performance can occur because the job satisfaction obtained by an individual is very low so that it has an impact on work performance. The results of this study are not in line with the findings by Karimi \& Mohammadi (2020) which showed that the higher the spiritual intelligence, the less likely social competition friction will occur in particular jobs, which is expected to result in better performance. The fact is supported by a study by Hartanto et al., (2017) which stated that spiritual intelligence had a positive effect on performance through job satisfaction.

\section{Conclusion}

The results of this study indicate that of the seven hypotheses developed, there are two accepted hypotheses, namely for the effect of emotional intelligence on job satisfaction, it is found that there is a significant influence and the influence of spiritual intelligence on teacher performance is also obtained significant results. While the development of the rejected hypothesis is found in the second hypothesis between the influence of spiritual intelligence on satisfaction, which is not significant. A person who has good spiritual intelligence may not be able to apply it optimally in his work-related life. The job satisfaction obtained by a teacher is basically related to what is obtained from an increase in performance. Furthermore, the results in the third hypothesis explain that emotional intelligence does not have a significant effect on teacher performance. Limitations and inability to manage emotions result in a lack of understanding of oneself and others, resulting in weak effectiveness at work. This condition triggers teacher performance to be less than optimal in the implementation process when using emotional intelligence. For the rejected hypothesis, then there is a fifth hypothesis, namely the effect of job satisfaction on teacher performance, which is not significant. This is because the conditions of the nonphysical work environment in schools have not supported the increase in teacher creativity in encouraging teaching and learning activities. With the lack of support from non-physical working conditions, This implies the weak satisfaction received by teachers so that it has an impact on sub-optimal performance. Furthermore, for the sixth hypothesis, the results show that job satisfaction is not able to mediate the relationship between emotional intelligence and teacher performance. If individuals have a negative emotional response to job-related satisfaction, they often adjust their own responses in describing the job from that emotional perspective. Then, for the seventh hypothesis, the results show that job satisfaction is not able to mediate the relationship between spiritual intelligence and teacher performance. A person who has a high level of spirituality is often faced with the choice to feel a different level of satisfaction.

\section{References}

Ahmadiansah, R. (2016). Pengaruh Motivasi Kerja Dan Kepuasan Kerja Terhadap Kinerja Guru Smk Muhammadiyah Salatiga. Inject: Interdisciplinary Journal of Communication, 1(2), 223-236. http://library1.nida.ac.th/termpaper6/sd/2554/19755.pdf.

Alfany, L. N. (2017). Pengaruh Kecerdasan Emosional Terhadap Kinerja Karyawandengan Kerpuasan Kerja Sebagai Variabel Intervening Pada Ptbank Pembangunan Daerah Jawa Timur Cabang $\begin{array}{lllll}\text { Sidoarjo. Jurnal Ilmu } & \text { Manajemen }\end{array}$ https://jurnalmahasiswa.unesa.ac.id/index.php/jim/article/download/19960/18262.

Amalini, H., Musadieq, M., \& Afrianty, T. (2016). Pengaruh Locus Of Control Terhadap Kepuasan Kerja Dan Kinerja (Studi Pada Karyawan Perusahaan Daerah Air Minum (Pdam) Kota Malang). Jurnal $\begin{array}{lll}\text { Administrasi } \quad \text { Bisnis, } & \text { 68-77), }\end{array}$ http://administrasibisnis.studentjournal.ub.ac.id/index.php/jab/article/view/1344.

Arda, M. (2017). Pengaruh Kepuasan Kerja Dan Disiplin Kerja Terhadap Kinerja Karyawan Pada Bank Rakyat Indonesia Cabang Putri Hijau Medan. Jurnal Ilmiah Manajemen Dan Bisnis, 18(1), 45-60. 
https://doi.org/10.30596/jimb.v18i1.1097.

Argon, B., \& Liana, Y. (2020). Kecerdasan Emosional Terhadap Komitmen Organisasi Melalui Kepuasan Kerja. Aktiva: Jurnal Akuntansi Dan Investasi, 4(1), 1-14. http://ejournal.unira.ac.id/index.php/jurnal_aktiva/article/view/822.

Auda, R. M. (2016). Pengaruh Kecerdasan Emosional Terhadap Komitmen Organisasi Melalui Kepuasan Kerja Sebagai Variabel Mediasi pada Bank DKI Kantor Cabang Surabaya. BISMA (Bisnis Dan Manajemen), 8(2), 156. https://doi.org/10.26740/bisma.v8n2.p156-176.

Budiwibowo, S. (2017). Pengaruh Gaya Kepemimpinan Transaksional, Transformasional Dan Disiplin Kerja Terhadap Kinerja Guru (Karyawan) Di Kota Madiun. Premiere Educandum: Jurnal Pendidikan Dasar Dan Pembelajaran, 4(02), 119-132. http://ejournal.unipma.ac.id/index.php/PE/article/view/312.

Butarbutar, N., Chandra, E., \& Pakpahan, G. E. (2020). The Employee Performance Seen from the Aspects of Organizational Culture and Commitment at the Education Office of Pematangsiantar City. Jesya (Jurnal Ekonomi \& Ekonomi Syariah), 3(2), 380-388. https://doi.org/10.36778/jesya.v3i2.214.

Chin, W. W., Peterson, R. A., \& Brown, S. P. (2008). Structural Equation Modeling In Marketing: Some Practical Reminders Structural Equation Modeling In Marketing: Some Practical Reminders. Journal of Marketing Theory and Practice ISSN:, 16(4), 287-298. https://doi.org/10.2753/MTP1069-6679160402.

Chong, S. C., Falahat, M., \& Lee, Y. S. (2020). Emotional Intelligence And Job Performance Of Academicians In Malaysia. International Journal of Higher Education, 19(1), 69-80. https://eric.ed.gov/?id=EJ1234696.

Daud, F. (2012). Pengaruh Kecerdasan Emosional (EQ) Dan Motivasi Belajar Terhadap Hasil Belajar Biologi Siswa SMA 3 Negeri Kota Palopo. Jurnal Pendidikan Dan Pembelajaran Universitas Negeri Malang, 19(2), 243-255. http://journal.um.ac.id/index.php/pendidikan-danpembelajaran/article/view/3475.

Dwi Anjarini, A. (2018). Analisis Pengaruh Emotional Quotient, Intelligence Quotient dan Spiritual Quotient Terhadap Kepuasan Kerja dan Kinerja Guru di Sekolah Luar Biasa Negeri Batang. BBM (Buletin Bisnis \& Manajemen), 3(1), 28-40. http://dx.doi.org/10.47686/bbm.v3i1.35.

Ekowati, S., Finthariasari, M., Yulinda, A. T., \& Sonitra. (2020). Pengaruh Kecerdasan Intelektual, Kecerdasan Emosional, Dan Spiritual Terhadap Kinerja Guru Sdn Kecamatan Pino Bengkulu Selatan. Jurnal Entrepreneur Dan Manajemen Sains, 1(1), 10-19. http://jurnal.umb.ac.id/index.php/jems/article/view/615.

Fatati, M. A., Tobing, D. S., \& Hana, S. W. L. (2017). Pengaruh Kepuasan Kerja Dukungan Organisasi Dan Motivasi Kerja Terhadap Kinerja Guru Smk Swasta Di Kecamatan Sumbersari. Relasi: Jurnal Ekonomi, 8(2), 271-294. https://doi.org/10.31967/relasi.v13i2.118.

Ginoga, V. (2017). Pengaruh Budaya Organisasi, Kecerdasan Spiritual dan Motivasi terhadap Kinerja dan Kepuasan Kerja Karyawan pada PT PELINDO IV (Persero) di Makassar. JABE (Journal of Applied Business and Economic), 4(1), 66. http://dx.doi.org/10.30998/jabe.v4i1.1907.

Hair, J. F. (2014). Multivariat Data Analysis 7th Edition. Pearson Prentice Hall.

Hartanto, Hidayah, S., \& Harnoto. (2017). Peningkatan Kinerja Pegawai Melalui Kecerdasan Emosional, Kecerdasan Spiritual dan Kepuasan Kerja Pegawai di Kecamatan Gunungpati Kota Semarang. Jurnal Manajemen Dan Akuntansi, 24(43), 76-88. http://www.ejurnal.stiedharmaputrasmg.ac.id/index.php/JEMA/article/view/302.

Harum, W., Manullang, R. R., \& Hartiwi, D. C. (2015). Analisis Pengaruh Kepuasan Kerja Dan Motivasi Kerja Terhadap Kinerja Guru (Studi Kasus Di KB-TK-SD Santa Theresia I Pangkalpinang). Ilmiah Progresif Manajemen Bisnis, 8(2), 44-54. https://e-jurnal.stieibek.ac.id/index.php/JIPMB/article/view/156.

Hidayati, I. N., Setiawan, M., \& Solimun. (2013). Kecerdasan Emosional dan Kecerdasan Spiritual Pengaruhnya Terhadap Kepuasan Kerja Dan Kinerja Karyawan Studi Di Lembaga Penjaminan Mutu Pendidikan (LPMP) Nusa Tenggara Barat. Jurnal Aplikasi Manajemen, 11(4), 629-639. https://www.jurnaljam.ub.ac.id/index.php/jam/article/view/600. 
Jasour, M., \& Maleki Avarsin, S. (2016). The Relationship Between Attributional Style and Spiritual Intelligence and Job Performance of Employees of Tabriz University of Medical Sciences. Research and Development in Medical Education, 5(2), 55-61. https://doi.org/10.15171/rdme.2016.012.

Juliandi, A. (2018). Structural Equation Model Based Partial Least Square (SEM-PLS): Menggunakan SmartPLS. https://zenodo.org/record/2538001\#.X-YIiFUzbIU.

Karimi, J., \& Mohammadi, M. (2020). The Relationship Between Spiritual Intelligence and Aggression Among Elite Wrestlers in Hamadan Province of IRAN. Journal of Religion and Health, 59(1), 614622. https://doi.org/10.1007/s10943-017-0525-7.

Kaur, I., Shri, C., \& Mital, K. M. (2019). The Role of Emotional Intelligence Competencies in Effective Teaching and Teacher's Performance in Higher Education. Higher Education for the Future, 6(2), 188-206. https://doi.org/10.1177/2347631119840542.

Khodijah, N. (2014). Hubungan Antara Kecerdasan Spiritual dan Self-Efficacy dengan Kinerja Guru Madrasah Aliyah Al-Fatah Palembang. Ta'dib, 19(01), 1-22. https://doi.org/10.19109/td.v19i01.5

Koražija, M., Šarotar Žižek, S., \& Mumel, D. (2016). The Relationship between Spiritual Intelligence and Work Satisfaction among Leaders and Employees. Naše Gospodarstvo/Our Economy, 62(2), 51-60. https://doi.org/10.1515/ngoe-2016-0012.

Kulshrestha, S., \& Singhal, T. K. (2017). Impact of Spiritual Intelligence on Performance and Job Satisfaction: A Study on School Teachers. International Journal of Human Resource \& Industrial Research, 4(2), 1-6.

Lie, D., Sherly, S., Dharma, E., \& Sudirman, A. (2019). The Impact of Work Discipline and Work Ethic on the Teacher Performance of Sultan Agung Pematangsiantar Private Middle School Teachers T.A. 2018/2019. International Journal of Business Studies, 3(3), 125-135. https://doi.org/10.32924/ijbs.v3i3.83.

Mandala, E. A., \& Dihan, F. N. (2018). Pengaruh Kecerdasan Emosional Dan Kecerdasan Spiritual Pada Kepuasan Kerja Yang Berdampak Terhadap Kinerja Karyawan PT. Madu Baru Bantul, Yogyakarta. Kajian Bisnis STIE Widya Wiwaha, 26(1), 13-29. https://doi.org/10.32477/jkb.v26i1.127.

Mantu, A., Massaong, A. K., \& Asrin. (2018). Pengaruh Kecerdasan Emosional, Kecerdasan Spiritual, Dan Kecerdasan Intelektual Terhadap Pengembangan Karakter Guru Sekolah Dasar Negeri Di Kecamatan Botumoito. JPS: Jurnal Riset Dan Pengembangan Ilmu Pengetahuan, 3(1), 103-111. http://ejurnal.pps.ung.ac.id/index.php/JPS/article/view/170.

Mujiono, \& Faruk. (2020). Pengaruh Kecerdasan Emosinal, Kecerdasan Spiritual Dan Kompetensi Terhadap Kepuasan Kerja Pegawai Badan Keuangan Daerah Kabupaten Pasuruan. Journal of $\begin{array}{llll}\text { Economic And } & \text { Business, } & \text { 92-102. }\end{array}$ http://ejurnal.stieyapan.ac.id/index.php/JEB/article/view/66.

Mulyasari, I. (2019). Pengaruh Kecerdasan Emosional Dan Kompetensi Terhadap Kinerja Pegawai. Journal of Management Review, 2(2), 190. http://dx.doi.org/10.25157/jmr.v2i2.1786.

Narsih, D. (2017). Pengaruh Kompetensi dan Kepuasaan Kerja terhadap Kinerja Guru SMKN 23 Jakarta Utara. Utility: Jurnal Ilmiah Pendidikan Dan Ekonomi, 1(1), 94-102. https://doi.org/10.30599/utility.v1i1.67.

Pakpahan, G. E., Nababan, S., Simanjuntak, J., \& Sudirman, A. (2019). Pengaruh budaya organisasi, komunikasi dan kompetensi guru terhadap kinerja guru sma swasta sultan agung $\begin{array}{llll}\text { pematangsiantar. } & \text { Kurnal 131-138. }\end{array}$ http://journal.feb.unmul.ac.id/index.php/KINERJA.

Pakpahan, G. E., Sari, D. P., \& Butarbutar, N. (2020). Kinerja Pegawai Ditinjau Dari Aspek Kemampuan Intelektual dan Disiplin Kerja Pada Kantor Kecamatan Siantar Sitalasari. Jurnal Manajemen Bisnis, 2(1), 2-3. https://doi.org/10.38043/jmb.v17i2.2385.

Pamungkas, W., \& Jabar, C. S. A. (2014). Pengaruh Profesionalitas, Kepuasan Kerja Dan Iklim Organisasi Terhadap Kinerja Guru Smkn Di Kabupaten Boyolali. Jurnal Akuntabilitas Manajemen Pendidikan, 2(2), 265-278. https://doi.org/10.21831/amp.v2i2.2454.

Pande, P. M. (2012). Pengaruh Kecerdasan Intelektual, Kecerdasan Emosional Dan Kecerdasan Spiritual Pada Kinerja Alumni Fakultas Ekonomi Universitas Udayana (Studi Empiris Mahasiswa Maksi Dan 
$\begin{array}{llll}\text { PPAK). E-Jurnal } & \text { Akuntansi, } & 1(1), & 1-17 .\end{array}$ https://ocs.unud.ac.id/index.php/Akuntansi/article/view/1998.

Parawitha, G. A., \& Gorda, E. S. (2017). Pengaruh Kecerdasan Spiritual, Kecerdasan Emosional, Kepemimpinan Transformasional Terhadap Kepuasan Kerja dan Kinerja. Jurnal Ilmiah $\begin{array}{llll}\text { Manajemen Dan } & \text { Bisnis, } & \text { 135-143. }\end{array}$ http://journal.undiknas.ac.id/index.php/manajemen/article/view/2088.

Pujianti, \& Isroah. (2013). Pengaruh Motivasi Kerja Dan Disiplin Kerja Terhadap Kinerja Guru Sma Negeri 1 Ciamis. Kajian Pendidikan Akuntansi Indonesia, 2(1), 184-207. https://journal.uny.ac.id/index.php/jkpai/article/view/1191.

Purwanto, F. X. A. (2018). Pengaruh Kecerdasan Emosional, Kecerdasan Spiritual dan Komitmen Organisasi terhadap Kepuasan Kerja Pegawai PT . Pelindo Marine Surabaya ( Effect of Emotional Intelligence, Spiritual Intelligence, and Organizational Commitment to Employee Satisfaction. Jurnal Humaniora, 15(1), 1-7.

Rachmelya, E., \& Suryani, A. (2017). Pengaruh Kecerdasan Emosional Dan Stres Kerja Terhadap Kepuasan Kerja Dan Dampaknya Terhadap Komitmen Organisasi Frontliner Bakti Pt Bank Central Asia Tbk Kcu Jambi. EKONOMIS: Journal of Economics and Business, 1(1), 51. http://ekonomis.unbari.ac.id/index.php/ojsekonomis/article/view/7.

Rahmawati, Z., \& Gunawan, J. (2019). Hubungan Job-related Factors terhadap Work- life Balance dan Kepuasan Kerja pada Pekerja Generasi Milenial. Jurnal SAINS Dan Seni ITS, 8(2), 3-8. http://dx.doi.org/10.12962/j23373520.v8i2.47782.

Riski, M. S., \& Riana, A. (2018). Pengaruh Disiplin Kerja , Kepemimpinan Transformasional dan Kecerdasan Emosional Terhadap Kepuasan dan Kinerja PNS Pada Bagian Umum dan Protokol Sekretariat Daerah Kabupaten Kutai Timur. Festival Riset Ilmiah Manajemen \& Akuntansi, 709-719.

Robbil Alifah, F. (2017). Pengaruh Kecerdasan Intelektual Dan Spiritual Terhadap Kinerja Melalui Motivasi Dan Kepuasan Kerja. Bisma Jurnal Bisnis Dan Manajemen, 11(1), 91-108. https://doi.org/10.19184/bisma.v11i1.6211.

Rosita, T., \& Yuniati, T. (2016). Pengaruh Budaya Organisasi Dan Kepuasan Kerja Terhadap Kinerja Karyawan Dengan Komitmen Organisasi Sebagai Variabel Intervening. Jurnal Ilmu Dan Riset Manajemen, 5(1). https://doi.org/10.33370/jpw.v21i2.342.

Sahir, H. S., Abdurrozzaq, H., Aisyah, S., Sudirman, A., Kusuma, A. H. P., Salmiah, Afriany, J., \& Simarmata, J. (2020). Gagasan Manajemen (A. Rikki (ed.); Cetakan 1). Yayasan Kita Menulis.

Sarwono, J. (2016). Membuat Skripsi, Tesis dan Disertasi dengan Partial Least Square SEM (PLS - SEM). Andi Offset.

Setyowati, D. R., Raharjo, T. J., \& Utomo, F. B. (2019). The Effect of Emotional Intelligence and Leadership of Principal Towards Teacher Performance of Vacational School With Motivation As Moderating $\begin{array}{llll}\text { Variable. } & \text { Educational }\end{array}$ https://journal.unnes.ac.id/sju/index.php/eduman/article/view/27814.

Sibasopait, A. B. (2018). Pengaruh Kecerdasan Intelektual, Kecerdasan Emosional, Dan Kecerdasan Spiritual Terhadap Kinerja Melalui Kepuasan Kerja Tenaga Kependidikan Di Kantor Pusat Universitas Jember. Bisma Uurnal Bisnis Dan Manajemen), 12(2), 212. https://doi.org/10.19184/bisma.v12i2.7891.

Slamet, T. R., Akbar, M., \& Muhtadi. (2020). Pengaruh Emotional Intelligence Terhadap Kepuasan Kerja Guru Pendamping Khusus (Gpk) Pada Smp Inklusi Di Jawa Barat. Prosiding Seminar Nasional $\begin{array}{llll}\text { Pascasarjana Universitas Negeri 338-343. } & \text { Jakarta, }\end{array}$ http://journal.unj.ac.id/unj/index.php/semnas-ps/article/view/16907.

Sulastyaningrum, R., Martono, T., \& Wahyono, B. (2019). Pengaruh Kecerdasan Intelektual, Kecerdasan Emosional, dan Kecerdasan Spiritual terhadap Prestasi Belajar Mata Pelajaran Ekonomi pada Peserta Didik Kelas XI IPS di SMA Negeri 1 Bulu Tahun Ajaran 2017/2018. BISE: Jurnal Pendidikan Bisnis Dan Ekonomi, 4(2), 1-19. https://jurnal.fkip.uns.ac.id/index.php/ptn/article/view/12445.

Ula, N. W. (2020). Analisis Pengaruh Kecerdasan Emosional Terhadap Kinerja Karyawan Melalui Kepuasan Kerja Pada Karyawan Divisi produksi PT. IKSG. Jurnal Ilmu Manajemen, 8(2), 376-384. 
https://jurnalmahasiswa.unesa.ac.id/index.php/jim/article/view/31277.

Usman, F. (2019). Pengaruh Kecerdasan Emosi Dan Budaya Organisasi Terhadap Kinerja Melalui Kepuasan Sebagai Variabel Intervening Pada Pegawai Universitas Trunajaya Bontang. Forum Ekonomi, 21(2), 132-142. http://dx.doi.org/10.29264/jfor.v21i2.5849.

Vasumathi, A., Sagaya, M. T., \& Poranki, K. R. (2019). The Impact Of Emotional Intelligence On Work Life Balance Among The Faculty Members' Performance In The Private Universities Using Multivariate Analysis, Tamil Nadu, India - An Empirical Study. International Journal of Services and Operations Management, 34(1), 1-20. https://doi.org/10.1504/IJSOM.2019.102028.

Wahyudi, T. (2019). Analisis Pengaruh Motivasi Kerja (Factor Intervening), Budaya Dan Kecerdasan Spiritual Terhadap Kepuasan Kerja Karyawan Politeknik Api Yoygakarta. Jurnal Ekonomi Dan Pariwisata, 1(1), 81-91. http://repository.poltekapi.ac.id/id/eprint/6.

Weliyanto. (2020). Pengaruh Kepuasan, Motivasi, Loyalitas, Dan Pemberian Penghargaan Terhadap Kinerja Guru SMA Dan SMK Di Kabupaten Berau. Jurnal Penelitian Administrasi Publik, 6(2), 202218. https://doi.org/10.30996/jpap.v6i2.4297.

Werang, B. R. (2014). Pengaruh Kepemimpinan Transformasional Kepala Sekolah, Moral Kerja Guru, Dan Kepuasan Kerja Terhadap Kinerja Guru Sdn Di Kota Merauke. Cakrawala Pendidikan, 33(1), 128137. https://doi.org/10.21831/cp.v1i1.1869.

Yani, A. S., \& Istiqomah, A. (2016). Pengaruh Kecerdasan Intelektual dan Kecerdasan Emosional Terhadap Kinerja Karyawan Dengan Profesionalisme Sebagai Variabel Intervening (Studi Empiris Terhadap PT. JNE Service Center Utara 1). Media Studi Ekonomi, 19(2), 43-55. https://doi.org/10.18326/inject.v1i2.223-236. 